\title{
Microwave-assisted extraction in dry fruit of andean species Vaccinium meridionale: Experimental conditions on the recovery of total polyphenols
}

\section{Extração assistida por microondas para frutos da espécie andina Vaccinium meridionale: Condições experimentais na remoção de polifenóis totais}

\author{
Wilfred Edilberto Espinosa', Luis Carlos Arturo Garzón²*, Oscar Julio Medina
}

\author{
`Universidad Pedagogica y Tecnologica de Colombia Ringgold standard institution, Escuela de Ciencias Químicas, Tunja, Boyacá, Colombia \\ Universidad de Boyacá, Facultad de Ciencias e Ingeniería, Tunja, Boyacá, Colombia \\ *Corresponding author: Icgarzon@uniboyaca.edu.co \\ Received in June 7, 2017 and approved in August 16, 2017
}

\begin{abstract}
Due to their nutraceutical properties, the fruits of the species Vaccinium meridionale, which inhabit the Andean region, are of scientific interest. Microwave-assisted extraction has been applied to different vegetal matrices for to extract efficiently polyphenolic compounds. In this work we study in microwave assisted extraction processes, the effect on the extraction of total polyphenols in dried fruits of Vaccinium meridionale, using response surface methodology. The main objective of this research was to analyze the relationships between power, temperature, solid-liquid ratio, time and ethanol concentration in aqueous media on the effectiveness of total polyphenols recovery in dry fruits of Vaccinium meridionale. A central composite design face-centered with three levels for each variable was used: $\mathrm{P}=300-900 \mathrm{~W} ; \mathrm{T}=70-110^{\circ} \mathrm{C} ; \mathrm{L}: \mathrm{S}_{\text {rat. }}=30: 1-70: 1 \mathrm{~W} / \mathrm{W}$; $t=5-15 \mathrm{~min} ;[\mathrm{EtOH}]=0-80 \%$. In this sense, the effect of the input variables on the recovery of total polyphenols, the optimization process for maximum extraction, and the comparison to other solid-liquid extractions in terms of quantity of total polyphenols, are reported. It was found that the significant variables in the extraction process were ethanol concentration, temperature and time; the best yields were obtained in the range $[\mathrm{EtOH}]=44-49 \%, \mathrm{~T}=110^{\circ} \mathrm{C}$, and $\mathrm{t}=10-15 \mathrm{~min}$. In terms of quantity, time and consumption of energy, microwave-assisted extraction technique is more efficient than other solid-liquid extraction processes for the extraction of total polyphenols.
\end{abstract}

Index terms: Folin-Ciocalteu method; response surface methodology (RSM); nutraceutical properties.

\begin{abstract}
RESUMO
Devido a suas propriedades nutracêuticas em termos do conteúdo de polifenóis totais, os frutos da espécie andina Vaccinium meridionale tem associado um grande interesse cientifico. A extração assistida por microondas tem sido utilizada em diferentes matrizes vegetais para a remoção de forma eficiente de compostos polifenólicos que apresentam uma atividade biológica. Neste artigo são apresentados os principais resultados experimentais obtidos em diferentes processos de extração assistida por microondas, com respeito à quantia de polifenóis totais removidos em frutos secos de Vaccinium meridionale por meio da metodologia da superfície de resposta. O principal objetivo desta pesquisa foi analisar as relações entre as variáveis independentes da potência, a temperatura, a relação sólido-líquido, tempo e concentração de etanol com respeito à quantidade polifenóis totais extraídos de frutos secos de Vaccinium meridionale. Foi utilizado um desenho composto centrado nas caras com três diferentes níveis para cada variável: $\mathrm{P}=300-900 \mathrm{~W} ; \mathrm{T}=70-110^{\circ} \mathrm{C} ; \mathrm{L}: \mathrm{S}_{\text {rat. }}=$ 30:1 - 70:1 w/w; t = $5-15 \mathrm{~min} ;[\mathrm{EtOH}]=0-80 \%$. Foi utilizado o método de Folin-Ciocalteu para a quantificação de polifenóis totais com ácido gálico como molécula de referência. Neste sentido, foi reportado neste trabalho o efeito dos fatores de entrada com respeito a quantidade de polifenóis totais removidos, o processo de optimização para obter a máxima remoção possível, e também uma comparação dos resultados experimentais com outros processos de extração sólido-líquido. Foi achado que a concentração de etanol, a temperatura e o tempo foram a variáveis mais importantes no processo de extração. A máxima quantidade de recuperação achada neste trabalho foi obtida no intervalo $[\mathrm{EtOH}]=44-49 \%, \mathrm{~T}=110^{\circ} \mathrm{C}$ e $\mathrm{t}=10-15 \mathrm{~min}$. Em termos de quantidade, tempo e gasto de energia, a extração assistida por microondas é uma técnica eficiente para a remoção de polifenóis totais em frutos secos de Vaccinium meridionale.
\end{abstract}

Termos para indexação: Método de Folin-Ciocalteu; metodologia da superfície de resposta (RSM); propriedades nutracêuticas.

\section{INTRODUCTION}

Over the last decades, a greater interest has been placed on the importance of consuming fruits of Vaccinium genus due to their therapeutic effects. Compounds from the family of flavonoids and benzoic acids contained in those foods have shown antioxidant activity (Shahidi; Ambigaipalan 2015; Zielinska; Michalska 2016; Wang et al., 2017). These molecules are associated with oxidative stress phenomena in the organism, due to the delay and 
inhibition of the action of free radicals (FR), which, in turn, has been associated with the development of multiple diseases (Sen et al., 2010; Nardi et al., 2016; $\mathrm{Wu}$ et al., 2016). On the other hand, some flavonoid contained in dry fruits of this genera have both antimutagenic and antitumoral activity. Preservation and normalization effects have been observed in the cellular cycle (Vattem; Ghaedian; Shetty 2005; Gambini et al., 2015); DNA molecule repair in cellular lines of colon cancer, induction of apoptosis, inhibition of tumor invasion and angiogenesis, as well as decrease in swelling processes (Kumar; Dhatwalia; Dhawan, 2016; Kazan et al., 2016; Kazan et al., 2017). Inhibition of atherogenesis, quercetin-mediated plaque aggregation, increase in neuronal signalization and increase in insulin secretion, have also been found (Martineau et al., 2006; Perez; Duarte 2010; Krikorian et al., 2010). Some anthocyanins present in fruits of Vaccinium genus, aid in the treatment of microcirculation diseases in diabetic patients and provide stabilization effects of collagen in varicose veins and hemorrhoids. Furthermore, they prevent gastrointestinal disorders and presence of proanthocyanidins microbial activity (Seeram, 2006; Kaufman et al., 2006; Khoo; Falk, 2014).

The fruit of Vaccinium meridionale, a native species of the Andes, has caught attention due to its high content of anthocyanins, and in general, total polyphenols (TP). These fresh fruits are consumed on a regular basis in preparations, such as juice and jelly (Garzón et al., 2010). The fruit of Vaccinium meridionale has shown activity in the inhibition of lipid peroxidation of corn oil (Gaviria et al., 2009a), growth inhibition in colon cancer cell lines (Maldonado; Arango; Rojano, 2014), protective effects in HT1080 cells lines against reduction of viability induced by the rotenone (Sequeda et al., 2016), a significant reduction in cell viability from SW480 cancer cell line (Zapata et al., 2016; Agudelo et al., 2017); and cytotoxic activity of extracts in transformed leukemic cell lines (González et al., 2017).

Regarding the process of TP obtainment in plants, microwave-assisted extraction (MAE) is highlighted because it possesses several advantages as compared to other conventional techniques. For instance, MAE requires short time periods, low solvent and energy consumption. Irradiation with microwaves generates matter and thermal energy transport from the inside of the cell towards the outside, extracting the metabolites of interest in a homogeneous and efficient manner (Wang; Weller, 2006; Mandal; Mohan; Hemalatha, 2007; Dean, 2012; Leonelli; Veronesi; Cravotto, 2013).
In this paper the effect of power (P), temperature $(\mathrm{T})$, the liquid-solid ratio $\left(\mathrm{L}: \mathrm{S}_{\text {rat. }}\right)$, time $(\mathrm{t})$, and ethanol concentration $([\mathrm{EtOH}])$ in the solvent system on the amount of TP extracted in dry fruits of Vaccinium meridionale with MAE technique, are discussed. Response surface methodology (RSM) was employed in order to analyze, with a relatively small number of experimental points (Song et al., 2011), the relationships between the independent variables or factors and the response variable. In this work, a central composite design face-centered with three levels for each variable was used: $\mathrm{P}=300-900 \mathrm{~W} ; \mathrm{T}=70-110^{\circ} \mathrm{C} ; \mathrm{L}^{\mathrm{S}} \mathrm{S}_{\text {rat. }}=30: 1$ $70: 1 \mathrm{w} / \mathrm{w} ; \mathrm{t}=5-15 \mathrm{~min} ;[\mathrm{EtOH}]=0-80 \%$. Quantification of TP was performed by applying the colorimetric system of Folin-Ciocalteu (F-C) reagent, and gallic acid (GA) as a reference molecule. The analytical method was previously validated by Espinosa, Garzón and Medina (2016), in terms of selectivity, linearity, repeatability and accuracy. Experimental design, treatment of experimental data and optimization process were carried out using Design-Expert ${ }^{\mathbb{R}}$ software, trial version 9. The recovery efficiency is compared with other solid-liquid extraction processes.

\section{MATERIAL AND METHODS}

\section{Instrument and equipment}

Analytical balance Ohaus Explorer EX 224, capacity: $220 \mathrm{~g}$, uncertainty: $\pm 10^{-4} \mathrm{~g}$. Spectrophotometer Hach DR 5000, wavelength range: 190-1100 nm, wavelength accuracy: $\pm 1 \mathrm{~nm}$ between 200 and $900 \mathrm{~nm}$, photometric accuracy: $1 \%$ between $0.50-2.0$ absorbance. Microwave digestion/extraction system Sineo MDS-8G, precision control inside the system: $0.0-10.0 \pm 0.01$ $\mathrm{MPa}$, temperature control: $0-300 \pm 1{ }^{\circ} \mathrm{C}$, microwave frequency: $2450 \pm 50 \mathrm{MHz}$. Centrifuge Hettichrotina $46 \mathrm{~S}, 4000 \mathrm{rpm}$ max. Analytical mill IKAA 11. Oven Memmert UM400. Incubator shaker IKA KS 4000 ic control.

\section{Reagents}

Folin \& Ciocalteu's phenol reagent 2N, Merck. Gallic acid monohydrate, $\geq 0.99$ in mass fraction, Panreac, (PubChem CID: 370). Absolute Ethanol for analysis EMSURE ${ }^{\circledR}$, Merck, (PubChem CID: 702). Sodium carbonate monohydrate A.R., $\geq 0.999$ in mass fraction, Mallinckrodt (PubChem CID: 10340). Ultrapure degasified water (type I), Pall Corporation Cascade LS $^{\circledR}$ system, conductivity: $0.056 \mu \mathrm{S} \mathrm{cm}^{-1}$. 


\section{Collection of Vaccinium meridionale fresh fruits}

Fresh fruits of Vaccinium meridionale were collected from a native habitat located in the municipality of Chiquinquirá (Boyacá, Colombia), latitude 5600, longitude 73800, and altitude between 2500 and $2600 \mathrm{masl}$; average precipitation $990 \mathrm{~mm}$ a year, average temperature $12.9{ }^{\circ} \mathrm{C}$, maximum $19.3{ }^{\circ} \mathrm{C}$ and minimum $7.4{ }^{\circ} \mathrm{C}$. Once collected, they were placed in polypropylene plastic bags and immediately carried out to the laboratory. Leaves and stems were removed manually and consequently washing with type I ultrapure degasified water.

\section{Vaccinium meridionale dry fruit processing}

The fresh fruits of Vaccinium meridionale were dried in a Memmert UM400 oven at $40{ }^{\circ} \mathrm{C}$, until the mass of the plant material remained constant for 12 hours. Consequently, the dried fruit was milled in an IKAA 11 analytical mill, and the sample was sieved through a sieve of $0.5 \mathrm{~mm}$ pore size. Particles of less than or equal to 0.5 $\mathrm{mm}$ were stored in a desiccator and frozen at $-4{ }^{\circ} \mathrm{C}$.
Microwave-assisted Vaccinium meridionale fruit extracts

Dry fruit (Dw) were weighed in a range of 281.7-645.2 $\pm 0.1 \mathrm{mg}$ and mixed in 19354.8-19718.3 $\pm 0.1 \mathrm{mg}$ of solvent system $(0 \% \mathrm{EtOH}, 40 \% \mathrm{EtOH}$ and $80 \% \mathrm{EtOH})$. All weights were measured in an Ohaus explorer EX 224 analytical balance, with a capacity of $220 \mathrm{~g}$, and uncertainty $\pm 10^{-4} \mathrm{~g}$. The mixture obtained was homogenized at room temperature $\left(12-20{ }^{\circ} \mathrm{C}\right)$ in an incubator shaker IKA KS 4000 ic control for 5 minutes. Subsequently, it was led to the Sineo MDS-8G extraction/digestion microwave system, according to the required extraction conditions. Finally, the mixture was centrifuged at $4000 \mathrm{rpm}$ for 20 minutes in a Hettich rotina $46 \mathrm{~S}$ centrifuge. The obtained supernatant was tagged as MAE fruit extract. If it was necessary, aqueous extracts were stored in a refrigerator at $4{ }^{\circ} \mathrm{C}$ and ethanolic extracts in a freezer at $-4^{\circ} \mathrm{C}$. In any case, the time passed between obtaining and quantifying the extract did not exceed 24 hours. Figure 1 shows the general scheme.

\title{
$281.7-645.2 \mathrm{mg}$ of Vaccinium meridionale dry fruit
}

\author{
$19.355-19.718 \mathrm{~g}$ of solvent system \\ ( $0 \% \mathrm{EtOH}, 40 \% \mathrm{EtOH}$ and $80 \%)$

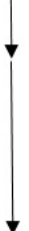 \\ Microwave-assisted extraction
}

Input variables: Power (P), temperature ( $\mathrm{T})$, the liquid-solid ratio $\left(\mathrm{L}: \mathrm{S}_{\text {rat. }}\right)$, time $(\mathrm{t})$, and ethanol concentration ([EtOH] $)$

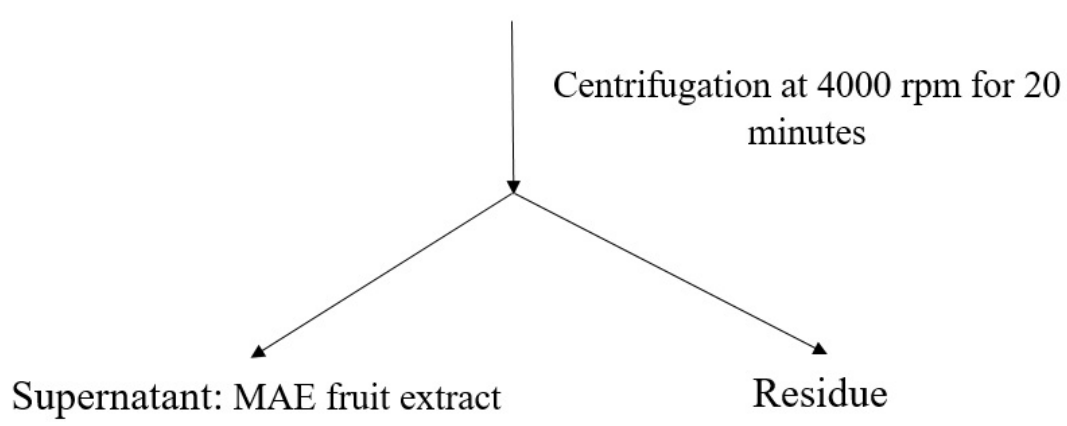

Figure 1: Scheme of the microwave-assisted extraction of total polyphenols in Vaccinium meridionale dry fruit. 


\section{Experimental design}

Central composite design face-centered was performed in order to assess the effect of five independent variables: power $(\mathrm{P})$, temperature $(\mathrm{T})$, liquid-solid ratio $\left(\mathrm{L}: \mathrm{S}_{\text {rat }}\right)$, time (t) and ethanol concentration $([\mathrm{EtOH}])$ in the ethanol-water solvent system. Response or dependent variable was TP recovered in mg of gallic acid per g of dry fruit (mg GA/g Dw). In total, 50 experimental points were carried out $(\mathrm{N}=$ $2^{\mathrm{k}}+2 \mathrm{k}+\mathrm{n}_{0}=2^{5}+2 \cdot 5+8=50$ ). Levels selected in each of the input factors were supported on the analysis of previous studies of TP extraction with MAE (Song et al., 2011; Ballard et al., 2010; Nayak et al., 2015; Gallo et al., 2010): $\mathrm{P}=(300$, $600,900) \mathrm{W} ; \mathrm{T}=(70,90,110){ }^{\circ} \mathrm{C} ; \mathrm{L}: \mathrm{S}_{\text {rat. }}=(30: 1,50: 1 ; 70: 1)$ $\mathrm{w} / \mathrm{w} ; \mathrm{t}=(5,10,15) \mathrm{min} ;[\mathrm{EtOH}]=(0,40,80) \%$. This study was limited to a maximum temperature of $110^{\circ} \mathrm{C}$, because the fruit of Vaccinium meridionale contains thermolabile compounds of a great therapeutic importance, such as resveratrol, catechin, and epicatechin (Garzón et al., 2010; Liazid et al., 2007). Ethanol was the solvent selected for its low toxicity, which makes it an ideal solvent to be used in pharmaceutical, cosmetic and food products (Mandal; Mohan; Hemalatha, 2007). The order of the experimental points, the modeling of experimental data and the optimization of process variables were performed using the Design-Expert ${ }^{\circledR}$ software, trial version 9. Statistical significance of the model and model parameters was determined at the $5 \%$ probability level. The adequacy of the model was determined by calculating the lack of fit, coefficient of determination $\left(\mathrm{R}^{2}\right)$ and the Fisher test value ( $F$-value) obtained from the analysis of variance (ANOVA) generated by the software. Table 1 shows the experimental design used in this study.

Table 1: Experimental design used in the extraction of TP with MAE.

\begin{tabular}{|c|c|c|c|c|c|c|c|c|c|c|c|}
\hline Run & $\begin{array}{c}X_{1}=P \\
(W)\end{array}$ & $\begin{array}{c}\mathrm{X}_{2}=\mathrm{T} \\
\left({ }^{\circ} \mathrm{C}\right)\end{array}$ & $\begin{array}{c}X_{3}=L: S_{\text {rat. }} \\
(\mathrm{g} / \mathrm{g})\end{array}$ & $\begin{array}{l}x_{4}=t \\
(\min )\end{array}$ & $\begin{array}{c}\mathrm{X}_{5}=[\mathrm{EtOH}] \\
(\%)\end{array}$ & Run & $\begin{array}{c}X_{1}=P \\
(W)\end{array}$ & $\begin{array}{c}\mathrm{X}_{2}=\mathrm{T} \\
\left({ }^{\circ} \mathrm{C}\right)\end{array}$ & $\begin{array}{c}X_{3}=L: S_{\text {rat. }} \\
(\mathrm{g} / \mathrm{g})\end{array}$ & $\begin{array}{l}X_{4}=t \\
(\min )\end{array}$ & $\begin{array}{c}\mathrm{X}_{5}=[\mathrm{EtOH}] \\
(\%)\end{array}$ \\
\hline 1 & 600 & 90 & 50 & 10 & 80 & 26 & 900 & 110 & 70 & 15 & 0 \\
\hline 2 & 600 & 110 & 50 & 10 & 40 & 27 & 300 & 110 & 30 & 15 & 0 \\
\hline 3 & 600 & 70 & 50 & 10 & 40 & 28 & 600 & 90 & 50 & 10 & 40 \\
\hline 4 & 300 & 90 & 50 & 10 & 40 & 29 & 300 & 70 & 30 & 15 & 0 \\
\hline 5 & 900 & 110 & 30 & 15 & 80 & 30 & 300 & 110 & 70 & 5 & 80 \\
\hline 6 & 600 & 90 & 50 & 10 & 40 & 31 & 600 & 90 & 30 & 10 & 40 \\
\hline 7 & 300 & 70 & 70 & 5 & 0 & 32 & 300 & 70 & 30 & 15 & 80 \\
\hline 8 & 900 & 70 & 30 & 5 & 0 & 33 & 900 & 70 & 70 & 5 & 0 \\
\hline 9 & 900 & 110 & 70 & 5 & 80 & 34 & 300 & 70 & 70 & 15 & 0 \\
\hline 10 & 900 & 70 & 70 & 15 & 80 & 35 & 300 & 110 & 30 & 5 & 80 \\
\hline 11 & 900 & 70 & 30 & 5 & 80 & 36 & 300 & 70 & 70 & 15 & 80 \\
\hline 12 & 300 & 110 & 70 & 15 & 80 & 37 & 300 & 70 & 30 & 5 & 0 \\
\hline 13 & 600 & 90 & 50 & 10 & 40 & 38 & 900 & 110 & 70 & 15 & 80 \\
\hline 14 & 900 & 110 & 30 & 5 & 80 & 39 & 300 & 70 & 30 & 5 & 80 \\
\hline 15 & 600 & 90 & 50 & 10 & 40 & 40 & 900 & 70 & 70 & 15 & 0 \\
\hline 16 & 900 & 110 & 70 & 5 & 0 & 41 & 300 & 110 & 70 & 5 & 0 \\
\hline 17 & 300 & 110 & 30 & 15 & 80 & 42 & 600 & 90 & 70 & 10 & 40 \\
\hline 18 & 600 & 90 & 50 & 10 & 40 & 43 & 600 & 90 & 50 & 10 & 40 \\
\hline 19 & 600 & 90 & 50 & 10 & 0 & 44 & 600 & 90 & 50 & 10 & 40 \\
\hline 20 & 300 & 110 & 30 & 5 & 0 & 45 & 900 & 110 & 30 & 5 & 0 \\
\hline 21 & 900 & 70 & 30 & 15 & 80 & 46 & 900 & 70 & 70 & 5 & 80 \\
\hline 22 & 300 & 110 & 70 & 15 & 0 & 47 & 900 & 70 & 30 & 15 & 0 \\
\hline 23 & 600 & 90 & 50 & 5 & 40 & 48 & 300 & 70 & 70 & 5 & 80 \\
\hline 24 & 900 & 110 & 30 & 15 & 0 & 49 & 600 & 90 & 50 & 15 & 40 \\
\hline 25 & 600 & 90 & 50 & 10 & 40 & 50 & 900 & 90 & 50 & 10 & 40 \\
\hline
\end{tabular}


Regarding the model generated by the software, the degree of agreement between the experimental results and the predicted quantities was evaluated by calculating the relative error. Six new extractions were also performed in the maximum recovery region predicted by the software and their differences were evaluated.

\section{Quantification of total polyphenols in extracts}

TP quantification was carried out through the colorimetric F-C method, according to analytical method validation proposed by Espinosa, Garzón and Medina (2016). Selectivity, linearity, repeatability and accuracy were the parameters validated. The major improvement of this quantification process was the employ of a gravimetric aliquot of the dry fruit extract instead of volumetric aliquot, which is commonly described in the literature (Turkmen; Sari; Velioglu, 2006; Rafiee et al., 2011; Blainski et al., 2013; Li et al., 2013; Hatami et al., 2014; Sim et al., 2016). Quantification process was performed as follow: fruit extracts were weighed directly into a $5-\mathrm{mL}$ volumetric flask ( $25-140 \pm 0.1 \mathrm{mg}$ of extract). $125 \mu \mathrm{L}$ of de F-C $2 \mathrm{~N}$ reagent were added to the flask and homogenized for 1 minute. Afterward, $400 \mu \mathrm{L}$ of sodium carbonate aqueous solution at $10 \%$ were added and diluted to the mark. It was homogenized for 30 seconds and left in the dark for 1 hour. Absorbance of the solution was measured at $760 \mathrm{~nm}$ wavelength in a Hach DR 5000 spectrophotometer. The quantities of TP contained in the extract, with gallic acid as a reference molecule, was calculated as shown in Equation 1:

$$
\mathrm{mg} \mathrm{GA} / \mathrm{g} \mathrm{Dw}=\frac{\mathrm{mg}_{\text {solv }} \cdot 5 \cdot 10^{-3} \mathrm{~L} \cdot(\mathrm{A}-b / \mathrm{m})}{\mathrm{mg}_{\mathrm{ext}} \cdot \mathrm{g} \mathrm{Dw}}
$$

Where $\mathrm{mg} \mathrm{GA} / \mathrm{g}$ Dw is the TP quantity recovered in $\mathrm{mg}$ of gallic acid per $\mathrm{g}$ of dry fruit, $\mathrm{mg}_{\text {solv }}$ is the mass of the solvent used to produce the extract (mg), A is absorbance of the diluted solution, $b$ the intercept of the calibration curve $(b=0.241 \pm 0.007), m$ the slope of the calibration curve $(m=0.869 \pm 0.001), \mathrm{mg}_{\text {ext }}$ the extract aliquot $(\mathrm{mg})$, and $\mathrm{g}$ Dw corresponds to the mass of the dry fruit used to produce the extract $(\mathrm{g})$.

\section{RESULTS AND DISCUSSION}

\section{Microwave-assisted extraction in dry fruits of Vaccinium meridionale}

Table 2 shows the TP obtained in each of the 50 experiments realized. The response variable obtained is found in the range of (18.8-40.2) $\mathrm{mg} \mathrm{GA} / \mathrm{g}$ Dw, showing a great influence of the experimental conditions over TP quantity recovered. By applying multiple regression analysis on the experimental data with Design-Expert ${ }^{\mathbb{B}}$ software trial version 9, the response variable and the independent factors were related by a second-order polynomial equation. Table 3 shows the analysis of variance (ANOVA) for response surface quadratic model. The model $F$-value of 70.18 implies the model is significant. There is only a $0.01 \%$ chance that a "model $F$-value" this large could occur due to noise. The "lack of fit $F$-value" of 1.33 implies the lack of fit is not significant relative to the pure error. There is a $36.94 \%$ chance that a "lack of fit $F$-value" this large could occur due to noise. The significance of each coefficient was evaluated using the $F$-test and $P$-values. It can be seen that all the linear terms, three quadratic and four interaction terms are significant ( $P$-values greater than 0.1000 indicate the model terms are not significant).

The reduced regression equation in terms of actual factors is presented as follows $\left(\mathrm{R}^{2}=0.9746\right)($ Equation 2$)$ :

$$
\begin{aligned}
& Y=444.2+0.0064 X_{1}-2.47 X_{2}+0.105 X_{3}- \\
& -0.88 X_{4}+0.580 X_{5}-0.00008 X_{1} X_{3}+ \\
& +0.0056 X_{2} X_{4}-0.0009 X_{3} X_{5}+0.0016 X_{4} X \\
& +0.0035 X_{2}^{2}-0.051 X_{4}^{2}-0.0061 X_{5}^{2}
\end{aligned}
$$

Power is expressed in $\mathrm{W}$, temperature in $\mathrm{K}, \mathrm{L}: \mathrm{S}_{\text {rat. }}$ in $\mathrm{g} / \mathrm{g}$, time in minutes, and $[\mathrm{EtOH}]$ in \%. In agreement with experimental results, a relation directly proportional to power and TP quantity along the interval studied, was found. Using quadratic polynomial by Equation 2, the pass from 300 to $900 \mathrm{~W}$ increases on average, extraction capacity in $1.4 \pm 0.7 \mathrm{mg} \mathrm{GA} / \mathrm{g}$ Dw. Temperature also presents a directly proportional relation. According to Equation 2, the pass from $70{ }^{\circ} \mathrm{C}$ to $110{ }^{\circ} \mathrm{C}$ generates, on average, an increase of $5.2 \pm 0.9 \mathrm{mg} \mathrm{GA} / \mathrm{g}$ Dw in extraction capacity. Conversely, there were no meaningful effects in the L:S ${ }_{\text {rat. }}$. The ratio from 1:30 to $1: 70$ generates, on average, an increase in the extraction capacity of $0.8 \pm$ $1.4 \mathrm{mg} \mathrm{GA} / \mathrm{g}$ Dw. Extractive capacity enhancements by the increase in the L:S $\mathrm{S}_{\text {rat. }}$ in systems with the power of $300 \mathrm{~W}$; if power is $600 \mathrm{~W}$ there is an inverse relation if [EtOH] is $80 \%$; and if power is $900 \mathrm{~W}$, the relationship is inverse when $[\mathrm{EtOH}]$ is 40 and $80 \%$. Time factor displays a direct relation up to $11.8 \mathrm{~min}$, after which it will be in the inverse way until the end of the interval studied. The span from 5 to 11.8 minutes generates, on average, an increase in the extraction capacity of $2.3 \pm 0.7 \mathrm{mg}$ $\mathrm{GA} / \mathrm{g}$ Dw. Finally, $[\mathrm{EtOH}]$ is directly proportional to the 
capacity of extraction, until it reaches a concentration of $45 \%$; afterward, the relation is inverted until the end of the interval considered. The change in concentration from $0 \%$ to $45 \%$ gives, on average, an increase in the extraction capacity of $12.4 \pm 0.7 \mathrm{mg} \mathrm{GA} / \mathrm{g} \mathrm{Dw}$. According to results described previously, we found that $[\mathrm{EtOH}]$ is the most important variable in the extraction process, followed by $\mathrm{T}, \mathrm{t}, \mathrm{P}$, and $\mathrm{L}: \mathrm{S}_{\text {rat. }}$.

Table 2: TP (mg GA/g Dw) obtained in extraction processes with MAE, according to experimental design described in Table 1.

\begin{tabular}{|c|c|c|c|c|c|c|c|c|c|}
\hline Run & $\begin{array}{c}\text { TP } \\
(m g G A / g D w)^{a}\end{array}$ & Run & $\begin{array}{c}\text { TP } \\
(\mathrm{mgGA} / \mathrm{gDw})^{\mathrm{a}}\end{array}$ & Run & $\begin{array}{c}\text { TP } \\
(m g G A / g D w)^{a}\end{array}$ & Run & $\begin{array}{c}\text { TP } \\
(\mathrm{mgGA} / \mathrm{gDw})^{\mathrm{a}}\end{array}$ & Run & $\begin{array}{c}\text { TP } \\
(\mathrm{mgGA} / \mathrm{gDw})^{\mathrm{a}}\end{array}$ \\
\hline 1 & 27.7 & 11 & 26.0 & 21 & 26.4 & 31 & 37.2 & 41 & 24.9 \\
\hline 2 & 40.2 & 12 & 31.4 & 22 & 26.9 & 32 & 24.2 & 42 & 35.3 \\
\hline 3 & 33.4 & 13 & 33.5 & 23 & 33.7 & 33 & 21.7 & 43 & 34.4 \\
\hline 4 & 36.2 & 14 & 30.7 & 24 & 26.6 & 34 & 22.3 & 44 & 34.8 \\
\hline 5 & 33.9 & 15 & 34.8 & 25 & 34.3 & 35 & 27.5 & 45 & 26.0 \\
\hline 6 & 34.2 & 16 & 25.7 & 26 & 28.5 & 36 & 26.3 & 46 & 25.1 \\
\hline 7 & 21.2 & 17 & 33.4 & 27 & 22.8 & 37 & 18.9 & 47 & 20.5 \\
\hline 8 & 20.1 & 18 & 36.7 & 28 & 34.8 & 38 & 32.8 & 48 & 23.8 \\
\hline 9 & 28.4 & 19 & 23.5 & 29 & 18.8 & 39 & 23.7 & 49 & 34.5 \\
\hline 10 & 25.6 & 20 & 20.5 & 30 & 28.7 & 40 & 22.5 & 50 & 34.7 \\
\hline
\end{tabular}

Table 3: ANOVA for response surface quadratic model for the experimental results of TP contents from dry fruits Vaccinium meridionale extracts with MAE.

\begin{tabular}{crrrrr}
\hline Source & Degree of Freedom & Sum of Squares & Mean Square & F-value & P-value \\
\hline Linear & & & & & \\
$X_{1}$ & 1 & 17.04 & 17.04 & 15.35 & 0.0005 \\
$X_{2}$ & 1 & 228.98 & 228.98 & 206.19 & $<0.0001$ \\
$X_{3}$ & 1 & 5.67 & 5.67 & 5.11 & 0.0315 \\
$X_{4}$ & 1 & 28.20 & 28.20 & 25.39 & $<0.0001$ \\
$X_{5}$ & 1 & 208.36 & 208.36 & 187.63 & $<0.0001$ \\
Quadratic & & & & & \\
$X_{1}^{2}$ & 1 & 0.037 & 0.037 & 0.034 & 0.8600 \\
$X_{2}^{2}$ & 1 & 3.68 & 3.68 & 3.31 & 0.0791 \\
$X_{3}^{2}$ & 1 & 1.21 & 1.21 & 1.09 & 0.3043 \\
$X_{4}^{2}$ & 1 & 5.23 & 5.23 & 4.71 & 0.0383 \\
$X_{5}^{2}$ & 1 & 245.00 & 245.00 & 220.63 & $<0.0001$ \\
Interaction & & & & & \\
$X_{1} X_{2}$ & 1 & 1.92 & 1.92 & 1.73 & 0.1984 \\
$X_{1} X_{3}$ & 1 & 7.52 & 7.52 & 6.77 & 0.0144 \\
$X_{1} X_{4}$ & 1 & 0.39 & 0.39 & 0.35 & 0.5611 \\
\hline
\end{tabular}


Table 3: Continuation...

\begin{tabular}{ccrrrr}
\hline$X_{1} X_{5}$ & 1 & 0.82 & 0.82 & 0.74 & 0.3959 \\
$X_{2} X_{3}$ & 1 & 0.48 & 0.48 & 0.43 & 0.5159 \\
$X_{2} X_{4}$ & 1 & 9.92 & 9.92 & 8.93 & 0.0057 \\
$X_{2} X_{5}$ & 1 & 2.96 & 2.96 & 2.67 & 0.1132 \\
$X_{3} X_{4}$ & 1 & 0.38 & 0.38 & 0.34 & 0.5622 \\
$X_{3} X_{5}$ & 1 & 16.44 & 16.44 & 14.80 & 0.0006 \\
$X_{4} X_{5}$ & 1 & 3.22 & 3.22 & 2.90 & 0.0995 \\
Model & 20 & 1558.65 & 77.93 & 70.18 & $<0.0001$ \\
Residual & 29 & 32.20 & 1.11 & & \\
Lack of Fit & 22 & 25.97 & 1.18 & 1.33 & 0.3694 \\
Pure Error & 7 & 6.23 & 0.89 & & \\
Corr. Total & 49 & 1590.85 & & & \\
\hline
\end{tabular}

Figure 2 shows, an example of the behavior of $[\mathrm{EtOH}]$ on recovery capacity. The variables considered are $\mathrm{T}$ and $\mathrm{t}$, whereas $\mathrm{P}$ and $\mathrm{L}: \mathrm{S}_{\text {rat. }}$ remain constant at their central points $\left(\mathrm{P}=600 \mathrm{~W} ; \mathrm{L}: \mathrm{S}_{\text {rat. }}=50: 1\right)$. The upper figure shows the response surface obtained when $[\mathrm{EtOH}]=0 \%$; the figure placed on the middle shows maximum recovery surface when $[\mathrm{EtOH}]=44 \%$; and the lower figure shows response surface when [EtOH] $=80 \%$. It is to focal point the great influence of [EtOH] on the efficiency of the process. Several authors have previously reported the importance of $[\mathrm{EtOH}]$ on the recovery of TP with MAE. For example, the extraction of TP from leaves of Ipomoea batatas (Song et al., 2011), in green tea leaves (Camellia sinensis) (Quan et al., 2006), and blackberry fruits Morus alba L. (Teng; Lee, 2013). Also, Xiao et al. (2008), highlighted the effect of $[\mathrm{EtOH}]$ on the extraction of flavonoids in Radix astragali.

Figure 3 shows an example of the behavior of temperature relative to TP extraction. Variables $\mathrm{P}$ and $[\mathrm{EtOH}]$ are included; variables $\mathrm{t}$ and $\mathrm{L}: \mathrm{S}_{\text {rat. }}$ remain constant at their central points $\left(\mathrm{t}=10 \mathrm{~min} ; \mathrm{L}: \mathrm{S}_{\text {rat. }}=\right.$ $50: 1)$. The first figure shows the response surface obtained when the temperature is at the lowest limit of the experimental design $\left(\mathrm{T}=70^{\circ} \mathrm{C}\right)$, and the last figure represents the surface obtained at the highest limit $\left(\mathrm{T}=110^{\circ} \mathrm{C}\right)$. In this example, we note the increase in TP obtainment by temperature increase under all experimental conditions, in which $\mathrm{P}$ and $[\mathrm{EtOH}]$ are considered. Recovery is minimum in the lowest limit and maximum in the highest limit. Destruction of vegetable cells exposed to microwaves is promoted when the temperature of the system increases, due to an enhancement in solute mass transfer rate into the matrix, increasing its solubility and decreasing solvent viscosity and superficial tension (Ballard et al., 2010; Leonelli; Veronesi; Cravotto, 2013; Dahmoune et al., 2015). It is possible to expect in dry fruits of Vaccinium meridionale, an increase in the TP quantity extracted when the temperature is higher than $110^{\circ} \mathrm{C}$ such as has been reported in previous work (Liazid et al., 2007; Inglet et al., 2010). However, an increase in system temperature would affect the chemical stability of bioactive compounds such as resveratrol, catechin and epicatechin (Liazid et al., 2007; Garzón et al., 2010).

With respect to the time factor, the maximum recoveries have been obtained in conditions nearing at 11.8 minutes. Time of exposition is a key factor because, in an inefficient extraction process, overheating could extend thermal degradation of phenolic compounds (Liazid et al. 2007).

\section{Optimization of MAE conditions and verification of the model}

In order to establish the optimal conditions of TP microwave-assisted extraction in dry fruits of Vaccinium meridionale, an optimal range was determined using Design-Expert ${ }^{\circledR}$ software, trial version 9. Efficient extraction of TP requires a temperature of $110^{\circ} \mathrm{C}$ (the highest one used in this research), [EtOH] ranging between $44-49 \%$, and time between $10-15$ minutes. Both remaining factors power and liquid:solid ratio are 
not determinant variables, since high recoveries of TP are possible along all the intervals considered. In order to evaluate the suitability of the quadratic equation for described and optimized the amount of TP extracted, six different extractions were carried out in the range of maximum recovery. Table 4 shows the experimental quantity of TP extracted at each determination, the quantity of TP predicted by Equation 2, and the percentage difference between them. As it can be seen, the model predicts successfully the behavior obtained. On average, the differences between the experimental results and the values predicted by Equation 2 are similar to those found in the experimental design. We also found in three of these six assays a major recovery of TP compared to the quantities obtained in the experimental design (the maximum quantity of TP recovered was $40.2 \mathrm{mgGA} / \mathrm{gDw}$ at $600 \mathrm{~W}, 110^{\circ} \mathrm{C}, 50: 1$ $\mathrm{w} / \mathrm{w}$ liquid:solid ratio, 10 minutes, and $40 \% \mathrm{EtOH}$ (run $2)$ ). In this sense, response surface methodology was successfully applied for modelling and optimization of TP extraction in dry fruits of Vaccinium meridionale with the MAE technique.

\section{Efficiency in TP microwave-assisted extraction in dry fruit of Vaccinium meridionale respect to solid-liquid extraction methods}

Table 5 shows a comparison between the efficiency of extraction with MAE and solid-liquid extraction respect to TP quantity recovered in fruits of Vaccinium meridionale. Maximum recovery in each case was reported. For MAE results, assay 3 of Table 4 was considered as the maximum. In terms of efficiency, MAE is found to be between 8 to $35 \%$ better, as compared to solid-liquid extraction processes. It is possible that efficiency in the extraction of TP with MAE improves if $\mathrm{EtOH}$ is replaced by $\mathrm{MeOH}$ in the solvent system, as in the studies reported in literature. As previously indicated, EtOH was selected due to its low toxicity. It is also important to highlight the difference of time in the extraction processes. TP obtainment in dry fruits of Vaccinium meridionale with MAE is significantly higher than solid-liquid extraction, as proven in previous studies (Pan; Niu; Liu; 2002; Afoakwah et al., 2012; Chan et al., 2011; Li et al., 2011; Routray; Orsat, 2012). In energetic terms, MAE is also more efficient, since it requires lower energy consumption.
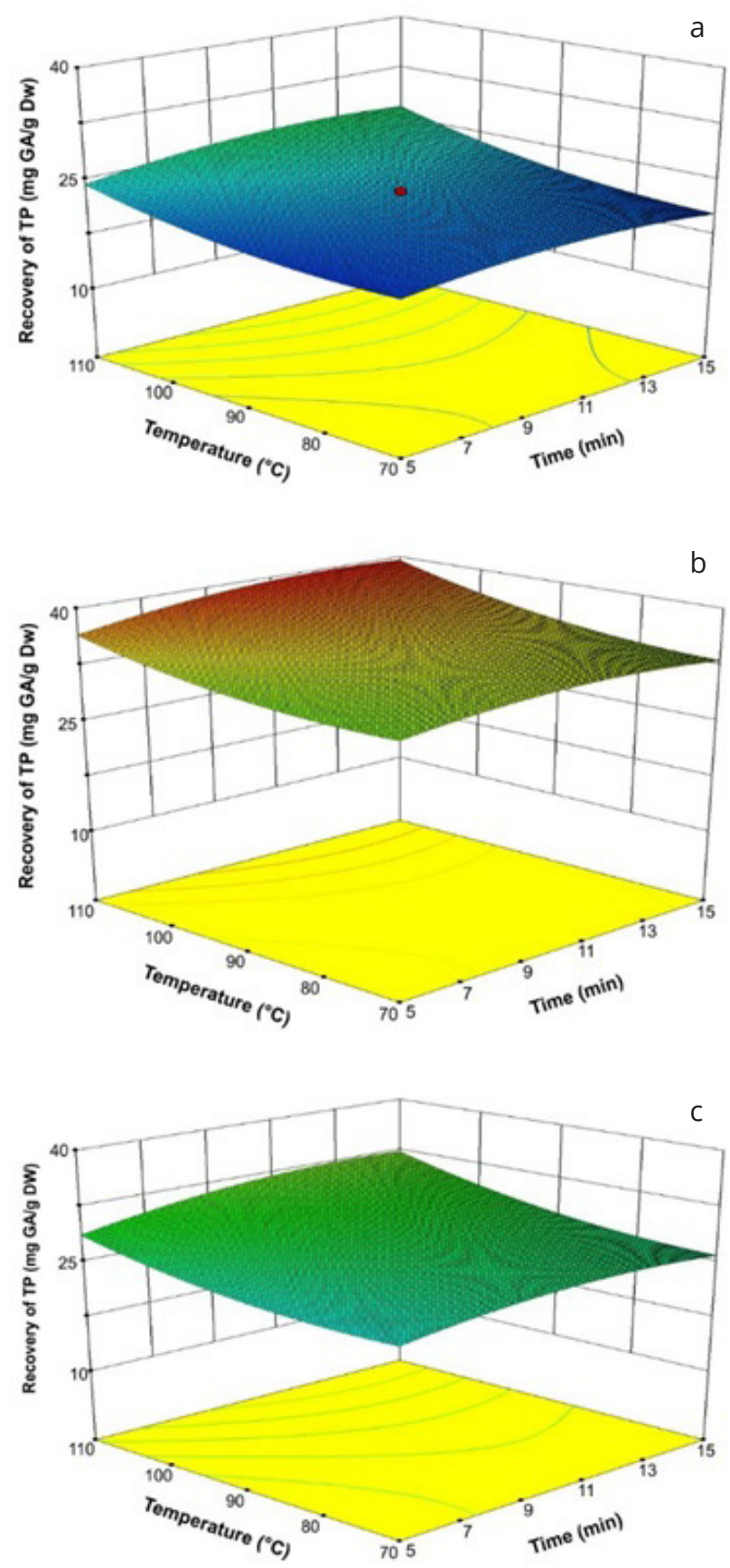

Figure 2: Effect of $[\mathrm{EtOH}]$ on the extraction of TP with MAE. Factors considered in the diagram: $T$ and $t$. Factors not considered in the diagram: $\mathrm{P}$ and $\mathrm{L}: \mathrm{S}_{\text {rat }}(\mathrm{P}$ $\left.=600 \mathrm{~W} ; \mathrm{L}: \mathrm{S}_{\text {rat. }}=50: 1\right)$. Upper: $[\mathrm{EtOH}]=0 \%$; middle: $[\mathrm{EtOH}]=44 \%$; lower: $[\mathrm{EtOH}]=80 \%$. 

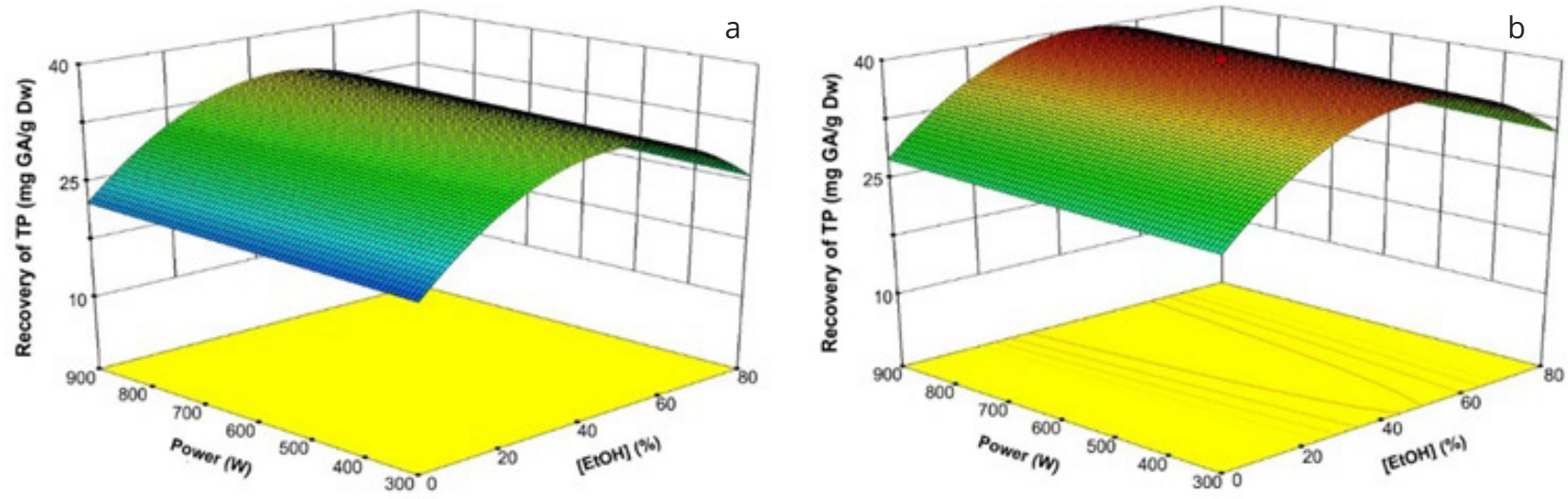

Figure 3: Effect of T on the extraction of TP with MAE. Factors considered in the diagram: $\mathrm{P}$ and [EtOH]. Factors not considered in the diagram: $t$ and $L: S_{\text {rat. }}\left(t=10 \mathrm{~min} ; \mathrm{L}: \mathrm{S}_{\text {rat. }}=50: 1\right)$. Left: $\mathrm{T}=70^{\circ} \mathrm{C}$; right: $\mathrm{T}=110^{\circ} \mathrm{C}$.

Table 4: TP (mg GA/g Dw) obtained in the range of experimental conditions with maximum recovery described by Equation 2.

\begin{tabular}{|c|c|c|c|c|c|c|c|c|}
\hline $\begin{array}{l}\text { Assay } \\
\text { number }\end{array}$ & $\begin{array}{l}X_{1}=P \\
(W)\end{array}$ & $\begin{array}{c}\mathrm{X}_{2}=\mathrm{T} \\
\left({ }^{\circ} \mathrm{C}\right)\end{array}$ & $\begin{array}{c}X_{3}=L: S_{\text {rat. }} \\
(\mathrm{g} / \mathrm{g})\end{array}$ & $\begin{array}{l}X_{4}=t \\
(\min )\end{array}$ & $\begin{array}{c}\mathrm{X}_{5}=[\mathrm{EtOH}] \\
(\%)\end{array}$ & 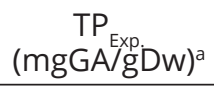 & $\begin{array}{l}\text { TP }_{\text {model }} \\
(\mathrm{mgGA} / g D w)^{\mathrm{b}}\end{array}$ & $\begin{array}{c}\text { Difference } \\
\%^{c}\end{array}$ \\
\hline 1 & 300 & 110 & 70 & 13 & 43.8 & 39.0 & 39.8 & 2.2 \\
\hline 2 & 600 & 110 & 70 & 13 & 44.9 & 40.4 & 40.1 & 0.8 \\
\hline 3 & 900 & 110 & 30 & 13 & 46.1 & 41.1 & 40.6 & 1.2 \\
\hline 4 & 900 & 110 & 50 & 13 & 47.8 & 39.6 & 40.4 & 2.0 \\
\hline 5 & 900 & 110 & 30 & 10 & 46.9 & 40.5 & 40.2 & 0.8 \\
\hline 6 & 900 & 110 & 30 & 15 & 48.7 & 38.4 & 40.4 & 5.4 \\
\hline
\end{tabular}

${ }^{a} u(T P) / T P= \pm 1.1 \% .{ }^{b}$ Standard deviation of TP recovery: $\pm 3.7 \% .{ }^{c}$ Difference $\%=\left(\left|\mathrm{TP}_{\text {model }}-\mathrm{TP}_{\text {Exp. }}\right| / \mathrm{TP}_{\text {Exp. }}\right) \cdot 100 \%$.

Table 5: Comparison of TP quantity recovered from dry fruits of Vaccinium meridionale with MAE and solid-liquid extraction processes.

\begin{tabular}{|c|c|c|c|c|}
\hline Authors & $\begin{array}{l}\text { Technique of } \\
\text { extraction }\end{array}$ & Conditions of extraction & $\begin{array}{l}\text { Recovery of TP } \\
\text { (mg GA/g Dw) }\end{array}$ & $\%$ efficacy $^{b}$ \\
\hline This work & MAE & $\begin{array}{l}\text { Solvent: EtOH-H } \mathrm{H}_{2} \mathrm{O}(46.1 \% \text { of EtOH }) \\
900 \mathrm{~W}, 110^{\circ} \mathrm{C}, \mathrm{L}: \mathrm{S}_{\text {rat. }}=50: 1(\mathrm{~W} / \mathrm{w}), 13 \text { minutes }\end{array}$ & 41.1 & - \\
\hline $\begin{array}{l}\text { Garzón, Narváez } \\
\text { and Riedl } 2010\end{array}$ & $\begin{array}{l}\text { Solid-liquid } \\
\text { extraction }\end{array}$ & $\begin{array}{c}\text { Solvent: } \mathrm{MeOH} \\
\text { Room temperature (not especified) }\end{array}$ & $37.9^{\mathrm{a}}$ & $8.4 \%$ \\
\hline $\begin{array}{l}\text { Gaviria et al. } \\
\quad(2009 a)\end{array}$ & $\begin{array}{l}\text { Solid-liquid } \\
\text { extraction }\end{array}$ & $\begin{array}{l}\text { Solvent: } \mathrm{MeOH}-\mathrm{HCl} 1 \%(6: 1 \mathrm{w} / \mathrm{v}) \\
\text { Room temperature (not especified) }\end{array}$ & $30.5^{a}$ & $34.8 \%$ \\
\hline
\end{tabular}

a Average value from experimental results for recovery of TP in mg GA per $100 \mathrm{~g}$ of fresh fruits, with an average humidity content of $80 \%$ (Gaviria et al., 2009b). ${ }^{\mathrm{b}} \%$ efficacy $=\left(\mathrm{TP}_{\text {from MAE }}-\mathrm{TP}_{\text {from S-L extraction }} / \mathrm{TP}\right.$ from S-L extraction $) \cdot 100 \%$. 


\section{CONCLUSIONS}

In this study, we found that $[\mathrm{EtOH}]$ is the most important variable for TP extraction in dry fruit of Vaccinium meridionale with MAE, followed by temperature, time, power and L:S ratio. Experimental results were described by a quadratic polynomial equation. A range of optimal conditions for TP obtainment was found and experimentally validated: $110^{\circ} \mathrm{C}$ of temperature, ethanol concentration between $44-49 \%$ and time between 10-15 minutes. MAE proved to be an effective technique for TP extraction in dry fruits of Vaccinium meridionale. TP extraction is more efficient between $8.4 \%$ and $34.8 \%$ than solid-liquid extraction processes wherever studied. Additionally, it is important to note the short periods for extraction and subsequent decrease in energy consumptions.

\section{REFERENCES}

AFOAKWAH, A. N. et al. Microwave Assisted Extraction (MAE) of antioxidant constituents in plant materials. Global Journal of Bioscience and Biotechnology, 1(2):132-140, 2012.

AGUDELO, C. D. et al. Antiproliferative and pro-apoptotic effects of Andean berry juice (Vaccinium meridionale Swartz) on human colon adenocarcinoma SW480 cells. Journal of Medicinal Plants Research, 11(24):393-402, 2017.

BALLARD, T. S. et al. Microwave-assisted extraction of phenolic antioxidant compounds from peanut skins. Food Chemistry, 20(4):1185-1192, 2010.

BLAINSKI, A. et al. Application and analysis of the Folin Ciocalteu Method for the determination of the total phenolic content from Limonium Brasiliense L. Molecules, 18(6):6852-6865, 2013.

CHAN, C. H. et al. Microwave-assisted extractions of active ingredients from plants. Journal of Chromatography A, 1218(37):6213-6225, 2011.

DAHMOUNE, F. et al. Optimization of microwave-assisted extraction of polyphenols from Myrtus communis L. leaves. Food Chemistry, 166(1):585-595, 2015.

DEAN, J. R. Microwave extraction. In: PAWLISZYN, J. Comprehensive sampling and sample preparation: Analytical techniques for scientists. Amsterdam: Elsevier. 2012. p. $135-149$.

ESPINOSA, W. E.; GARZÓN, L. C. A.; MEDINA, O. J. Validación de una metodología analítica para la cuantificación de polifenoles totales en procesos de extracción asistida por microondas sobre frutos de la especie Colombiana Vaccinium meridionale. Revista Colombina de Ciencias Químico-Farmacéuticas, 45(1):109-126, 2016.

GALLO, M. et al. Microwave assisted extraction of phenolic compounds from four different spices. Molecules, 15(9):6365-6374, 2010.

GAMBINI, J. et al. Properties of resveratrol: In vitro and In vivo studies about metabolism, bioavailability, and biological effects in animal models and humans. Oxidative Medicine and Cellular Longevity, Article ID 837042, 13 pages, 2015.

GARZÓN, G. A. et al. Chemical composition, anthocyanins, non-anthocyanin phenolics and antioxidant activity of wild bilberry (Vaccinium meridionale Swartz) from Colombia. Food Chemistry, 122(4):980-986, 2010.

GAVIRIA, C. A. et al. Actividad antioxidante e inhibición de la peroxidación lipídica de extractos de frutos de mortiño (Vaccinium meridionale SW). Boletín Latinoamericano y del Caribe de Plantas Medicinales y Aromáticas, 8(6):519-528, 2009a.

GAVIRIA, C. A. et al. Propiedades antioxidantes de los frutos de agraz o mortiño (Vaccinium meridionale Swartz). In: Ligarreto, G. A. Perspectivas del cultivo de agraz o mortiño en la zona altoandina de Colombia. Bogotá: Universidad Nacional de Colombia, 2009b, p.93-112.

HATAMI, T. et al. Total phenolic contents and antioxidant activities of different extracts and fractions from the aerial parts of Artemisia biennis willd. Iranian Journal of Pharmaceutical Research, 13(2):551-559, 2014.

INGLETT, G. E. et al. Phenolic content and antioxidant activity of extracts from whole buckwheat (Fagopyrum esculentum Möench) with or without microwave irradiation. Food Chemistry, 119(3):1216-1219, 2010.

KAUFMAN, P. B. et al. The uses of plant natural products by humans and risks associated with their use. In: CSEKE, L. J. et al. Natural Products from Plants. Boca Raton: Taylor \& Francis Group, 2006, p.441-473.

KAZAN, A. et al. Investigating anthocyanin contents and in vitro tumor suppression properties of blueberry extracts prepared by various processes. European Food Research and Technology, 242(5):693-701, 2016.

KAZAN, A. et al. In vitro tumor suppression properties of blueberry extracts in liquid and encapsulated forms. European Food Research and Technology, 243(6):10571063, 2017. 
KHOO, C.; FALK, M. Cranberry polyphenols: Effects on cardiovascular risk factors. In: WATSON, R. R.; PREEDY, V. R.; ZIBADI, S. Polyphenols in Human Health and Disease. San Diego: Academic Press, 2014, p.1049-1065.

KRIKORIAN, R. et al. Blueberry supplementation improves memory in older adults. Journal of Agricultural and Food Chemistry, 58(7):3996-4000, 2010.

KUMAR, M.; DHATWALIA, S. K.; DHAWAN, D. K. Role of angiogenic factors of herbal origin in regulation of molecular pathways that control tumor angiogenesis. Tumor Biology, 37(11):14341-14354, 2016.

LEONELLI, C.; VERONESI, P.; CRAVOTTO, G. Microwaveassisted extraction: An introduction to dielectric heating. In: CHEMAT, F.; CRAVOTTO, G. Microwave-assisted extraction for bioactive compounds: Theory and practice. New York: Springer, 2013, p.1-14.

$\mathrm{LI}, \mathrm{C}$. et al. Composition of polyphenols and antioxidant activity of rabbiteye blueberry (Vaccinium ashei) in Nanjing. Journal of Agricultural and Food Chemistry, 61(3):523-531, 2013.

Li, Y. et al. Microwave-assistance provides very rapid and efficient extraction of grape seed polyphenols. Food Chemistry, 129(2):570-576, 2011.

LIAZID, A. et al. Investigation on phenolic compounds stability during microwave-assisted extraction. Journal of Chromatography A, 1140(1-2):29-34, 2007.

MALDONADO, M. E.; ARANGO, S. S.; ROJANO, B. A. Free radical scavenging capacity and cytotoxic and antiproliferative effects of Vaccinium meridionale Sw. agains colon cancer cell lines. Revista Cubana de Plantas Medicinales, 19(2):172-184, 2014.

MANDAL, V.; MOHAN, Y.; HEMALATHA, S. Microwave assisted extraction - An innovative and promising extraction tool for medicinal plant research. Pharmacognosy reviews, 1(1):7-18, 2007.

MARTINEAU, L. C. et al. Anti-diabetic properties of the Canadian lowbush blueberry Vaccinium angustifolium Ait. Phytomedicine, 13(9):612-623, 2006.

NAYAK, B. et al. Comparison of microwave, ultrasound and accelerated-assisted solvent extraction for recovery of polyphenols from Citrus sinensis peels. Food Chemistry, 187(1):507-516, 2015.

NARDI, G. M. et al. Anti-inflammatory activity of berry fruits in mice model of inflammation is based on oxidative stress modulation. Pharmacognosy Research, 8(Suppl.1):S42-S49, 2016.
PAN, X.; NIU, G.; LIU, H. Comparison of microwave-assisted extraction and conventional extraction techniques for the extraction of tanshinones from Salvia miltiorrhiza bunge. Biochemical Engineering Journal, 12(1):71-77, 2002.

PEREZ, F.; DUARTE, J. Flavonols and cardiovascular disease. Molecular Aspects of Medicine, 31(6):478-494, 2010.

QUAN, P. T. et al. Microwave-assisted extraction of polyphenols from fresh tea shoot. Science and Technology Development, 9(8):69-75, 2006.

RAFIEE, Z. et al. Microwave-assisted extraction of phenolic compounds from olive leaves; a comparison with maceration. The Journal of Animal \& Plant Sciences, 21(4):738-745, 2011.

ROUTRAY, W.; ORSAT, V. Microwave-assisted extraction of flavonoids: A review. Food and Bioprocess Technology, 5(2):409-424, 2012.

SEERAM, N. P. Berries. In: HEBER, D. et al. Nutritional Oncology. Burlington: Academic Press, 2006, p.615628.

SEN, S. et al. Free radicals, antioxidants, diseases and phytomedicines: Current status and future prospect. International Journal of Pharmaceutical Sciences Review and Research, 3(1):91-100, 2010.

SEQUEDA, L. G. et al. Evaluation of antioxidant and cytotoxic activity of extracts from fruits in fibroblastoma HT1080 cell lines: Four fruits with commercial potential in Colombia. Emirates Journal of Food \& Agriculture, 28(2):143-151, 2016.

SHAHIDI, F.; AMBIGAIPALAN, P. Phenolics and polyphenolics in foods, beverages and spices: Antioxidant activity and health effects - A review. Journal of Functional Foods, 18:820-897, 2015.

SIM, S. Y. et al. Plant polyphenols to enhance the nutritional and sensory properties of chocolates. Food chemistry, 200(1):46-54, 2016.

SONG, J. et al. Optimized microwave-assisted extraction of total phenolics (TP) from Ipomoea batatas leaves and its antioxidant activity. Innovative Food Science \& Emerging Technologies, 12(3):282-287, 2011.

TENG, H.; LEE, W. Y. Optimization of microwave-assisted extraction of polyphenols from mulberry fruits (Morus alba L.) using response surface methodology. Journal of the Korean Society for Applied Biological Chemistry, 56(3):317-324, 2013. 
TURKMEN, N.; SARI, F.; VELIOGLU, S. Effects of extraction solvents on concentration and antioxidant activity of black and black mate tea polyphenols determined by ferrous tartrate and Folin-Ciocalteu methods. Food Chemistry, 99(4):835-841, 2006.

VATTEM, D. A.; GHAEDIAN, R.; SHETTY, K. Enhancing health benefits of berries through phenolic antioxidant enrichment: Focus on cranberry. Asia Pacific Journal of Clinical Nutrition, 14(2):120-130, 2005.

WANG, H. et al. Comparison of phytochemical profiles, antioxidant and cellular antioxidant activities of different varieties of blueberry (Vaccinium spp.). Food Chemistry, 217(15):773-781, 2017.

WANG, L.; WELLER, C. L. Recent advances in extraction of nutraceuticals from plants. Trends in Food Science \& Technology, 17(6):300-312, 2006.
XIAO, W.; HAN, L.; SHI, B. Microwave-assisted extraction of flavonoids from Radix Astragali. Separation and Purification Technology, 62(3):614-618, 2008.

WU, T. et al. Mulberry and cherry anthocyanin consumption prevents oxidative stress and inflammation in diet-induced obese mice. Molecular Nutrition \& Food Research, 60(3):687-694, 2016.

ZAPATA, I. C. et al. Cytotoxic effect and antioxidant activity of Andean berry (Vaccinium meridionale Sw) wine. Journal of Medicinal Plants Research, 10(27):402408, 2016.

ZIELINSKA, M.; MICHALSKA, A. Microwave-assisted drying of blueberry (Vaccinium corymbosum L.) fruits: Drying kinetics, polyphenols, anthocyanins, antioxidant capacity, colour and texture. Food Chemistry, 212(1):671-680, 2016. 